Інноватика у вихованні. Випуск 11. Том 1. 2020.

УДК 378.016:81'243

DOI: $\underline{10.35619 / \text { iiu.v1i11.208 }}$

Ясногурська Людмила

кандидат філологічних наук, доцент, доцент кафедри іноземних мов

Рівненського державного гуманітарного університету, м. Рівне, Україна ORCID: 0000-0003-3039-447X e-mail:ludmila12011@ukr.net

\title{
КОМПЕТЕНТНІСНИЙ ПІДХІД У НАВЧАННІ ІНОЗЕМНИМ МОВАМ
}

Анотація. Стаття присвячена способам реалізації компетентнісного підходу при викладанні іноземної мови у закладі вищої освіти. Розглядається низка загальнокультурних і професійних компетенцій, якими повинен володіти студент ЗВО. Важливість формування у студентів міжкультурної компетенції в навчанні іноземних мов продиктована радикальними змінами, які відбуваються в українському суспільстві як результат інтеграції країни до світового освітнього, інформаційного, економічного простору, що спонукає людину до вміння співіснувати у цьому просторі, тобто бути здатною i готовою будувати конструктивний діалог з усіма суб'єктами сучасного глобального світу. Орієнтація освітньо-виховного процесу в системі мовної освіти має здійснюватися на основі послідовного формування міжкультурної компетенції стосовно вирішення конкретних всеохоплюючих завдань е процесі навчання англійської мови. Автор стверджує, що міжкультурна компетенція не $\epsilon$ тотожною комунікативній компетенції носія мови, а являє собою таку здатність, яка дозволяє особистості вийти за межі власної культури і набути якості медіатора культур, втрачаючи власну особисту культурну ідентичність. Наголошується, що комунікативна компетентність студента, який навчається іншомовному спілкуванню - це здатність до повноцінного мовного спілкування в усіх сферах людської діяльності 3 дотриманням соціальних норм мовної поведінки.

Ключові слова: компетентність, комунікація, міжкультурні компетенції, спілкування, іноземна мова.

Постановка проблеми. Процеси глобалізації міжнародного простору збільшується можливість комунікації між людьми різних країн, народів. Однією 3 основних проблем, що ускладнюють комунікацію, $є$ проблема низького рівня міжкультурної компетенції особистості, у зв'язку з чим випускники ЗВО, як майбутні фахівці, не здатні соціально адаптуватися та інтегруватися ні в професійний соціум своєї країни, ні у світову спільноту. Перетворити сучасного студента з пасивного елемента освітньої системи в активного учасника освітнього процесу дозволяє компетентнісний підхід у процесі навчання іноземних мов.

Аналіз останніх досліджень 3 проблеми. Теоретико-методологічну основу дослідження, представленого в статті, склали: особистісно-орієнтований підхід до організації педагогічного процесу (О. Г. Асмолов, А. С. Бєлкін, С. В. Бондаревська, Л. І. Божович, С. Ф. Зеєр , А. В. Петровський, В. В. Сєріков, С. Г. Тер-Мінасова, I. С. Якиманська); концепція діалогу в пізнанні (М. М. Бахтін) та освіті (В. С. Біблер), в навчанні іноземних мов (О. М. Леонтьєв, С. І. Пассов); теорія міжкультурної комунікації (С. Р. Балуян, А. А. Воротнікова, Г. В. Слізарова, 
Ю. Н. Смельянов, М. Г. Корочкін, В. В. Сафонова, С. М. Соловова, С. Г. ТерМінасова, I. І. Халєєва); компетентнісний підхід до навчання іноземної мови (I. Бім, В. В. Віноградов, Н. Д. Гальскова, Ю. Н. Караулов, Г. О. Китайгородська, О. М. Леонтьєв, С. І. Пассов, С. Г. Тер-Мінасова, І. І. Халєєва, І. А. Цатурова).

Мета статті - довести, що саме компетентнісний підхід сприяє не тільки оволодіти певним багажем знань, а й навчає студента вмінню самостійно мислити і здобувати знання.

Виклад основного матеріалу дослідження. Компетенція - це коло діяльності, та область питань, у якій людина є добре обізнана. Компетентнісний підхід висуває на перше місце не інформованість студента, а вміння вирішувати проблеми, що виникають у таких ситуаціях: при освоєнні сучасної техніки і технологій; у взаєминах людей, в етичних нормах, при оцінці власних вчинків; у практичному житті при виконанні соціальних ролей громадянина, члена сім'ї, містянина, виборця; при виборі спеціалізації у своїй професійній діяльності, оцінці свого рівня підготовленості, в умінні орієнтуватися на ринку праці; при необхідності вирішувати особисті проблеми життєвого самовизначення, вибору стилю і способу життя, способів вирішення конфліктів.

Компетентнісний підхід у навчанні іноземних мов передбачає формування трьох основних компетенцій: лінгвістичної, комунікативної та міжкультурної. Лінгвістична (або мовна) компетенція передбачає володіння системою відомостей про мову, що досліджується, за іiі рівнями: фонетика, лексика, склад слова і словотвір, морфологія, синтаксис простого і складного речення, основи стилістики тексту. Студент володіє лінгвістичною компетенцією, якщо він має уявлення про систему, що вивчається і може користуватися цією системою на практиці. На якість мовної компетенції в мові, що вивчається, впливає не тільки ступінь володіння нею, але й рівень компетенції студентів у рідній мові. Мовна компетенція, за визначенням Н. Хомського, означає здатність розуміти і продукувати необмежену кількість правильних у мовному плані пропозицій за допомогою засвоєних мовних знаків і правил їх з'єднання.

У дослідженнях можна знайти різні поняття «мовна компетентність», наприклад, «мовна компетенція - здатність учня конструювати граматично правильні форми і синтаксичні побудови, а також розуміти смислові відрізки в промові, організовані відповідно до існуючих норм рідної мови, і використовувати їх в тому значенні, в якому вони вживаються носіями мови в ізольованій позиції» (Savignon, 1983).

Комунікативна компетенція передбачає знання про мови, іiі функції, розвиток умінь у чотирьох основних видах мовленнєвої діяльності (говоріння, аудіювання, читання, письмо). Комунікативна компетентність студента, що навчається іншомовному спілкуванню - це здатність до повноцінного мовного спілкування у всіх сферах людської діяльності, з дотриманням соціальних норм мовної поведінки. Основне ж уміння, що формується в межах комунікативної компетенції - це вміння створювати і сприймати тексти - продукти мовленнєвої діяльності. Комунікативна компетентність включає в себе знання основних понять лінгвістики мови - стилі, типи мовлення, будову опису, розповіді, міркування, способи зв'язку речень у тексті, вміння і навички аналізу тексту. Інакше кажучи, комунікативна компетенція визначається як «функціональна мовна здатність; вираз, інтерпретація і обговорення значення, включаючи взаємодію між двома або кількома індивідами, що належать до одного і того ж або різних мовних співтовариствах, або між одним індивідом і письмовим або усним текстом» (Боброва, 2015). 
Існують компоненти ситуації, або мовні умови, які диктують тому, хто говорить, вибір слів і граматичних засобів. Це, по-перше, взаємини між співрозмовниками i їх соціальні ролі. Немає сумніву, що характер мовного спілкування буде різним залежно від того, з ким спілкуємося, який їх соціальний статус, вік, стать, інтереси. По-друге, місце спілкування (наприклад, спілкування викладача і студента на занятті, під час перерви, в дружній бесіді). Третій, дуже важливий компонент мовної ситуації, - мета і наміри того, хто говорить. Зокрема, прохання чи вимога, звичайно, будуть відрізнятися від повідомлення, інформації чи їх емоційної оцінки, вияву подяки, радості, образи. Отже, власні комунікативні вміння і навички - це ті, які ми використовуємо в конкретно заданій ситуації. Немає сумніву, що їх формування є можливим лише на базі лінгвістичної або мовної компетенції. Третя компетенція - міжкультурна - $€$ важливим компонентом сучасної підготовки студента будь-якого закладу вищої освіти. Важливість формування у студентів міжкультурної компетенції в навчанні іноземних мов продиктована радикальними змінами, що відбуваються в українському суспільстві як результат інтеграції нашої країни до світового освітнього, інформаційного, економічного простору, що спонукає людину до вміння співіснувати в загальному життєвому світі, тобто бути здатною і готовою будувати конструктивний діалог 3 усіма суб'єктами цього простору. Орієнтація освітньо-виховного процесу в системі мовної освіти на послідовне формування міжкультурної компетенції передбачає вирішення таких завдань:

- навчання нормам міжкультурного спілкування іноземними мовами;

- соціокультурний розвиток студентів (одночасне вивчення рідної мови і рідної культури, іноземних мов і культур інших народів, розвиток у студентів умінь i навичок представляти свою країну i культуру в умовах іншомовного міжкультурного спілкування);

- формування у студентів поваги до інших народів і культур, готовності до ділової співпраці і взаємодії, до спільного вирішення загальнолюдських проблем.

Вивчення проблем міжкультурної комунікації передбачає знайомство 3 принципами комунікації, основними функціями культури, впливом культури на сприйняття і комунікацію в іiі різних сферах і видах, параметрами для опису впливу культури на людську діяльність і розвиток суспільства. Міжкультурна компетенція не $є$ тотожною комунікативній компетенції носія мови, вона являє собою таку здатність, яка дозволяє особистості вийти за межі власної культури і набути якості медіатора культур, не втрачаючи власну культурну ідентичність. Водночас, іншомовна комунікативна компетенція не $\epsilon$ аналогом комунікативної компетенції носія мови. Міжкультурна компетенція розуміється як частина комунікативної компетенції особистості, що вивчає іноземну мову. Справедливою є думка, що міжкультурна компетенція ніби «пронизує» всі складові частини комунікативної компетенції, $є$ їх фоном. Таким чином, термін «міжкультурна комунікація», який поєднує терміни «міжкультурна компетенція» і «комунікативна компетенція» в єдине ціле, означає спілкування людей, що представляють різні культури, при цьому партнери у спілкуванні усвідомлюють той факт, що кожен 3 них $є$ «іншим» і кожен по-своєму сприймає «чужорідність» партнера. Уміння спілкуватися в межах діалогу культур вимагає наявності в учня багатьох вмінь, які досить важко формуються, а саме: уміння ставити себе на місце інших; виявляти ініціативу щодо встановлення міжкультурного контакту; прогнозувати i розпізнавати соціокультурні прогалини, що призводять до непорозуміння; приймати відповідальність за усунення всілякого крос-культурного непорозуміння; виявляти дипломатичність 3 метою підтримки діалогу культур у дусі миру; бути 
повноцінним представником рідної культури; самонавчатися та функціонувати самостійно в полікультурному світі, використовуючи соціокультурні стратегії. Такий рівень володіння іноземною мовою, напевно, можна вважати ідеальним, і до цього ідеалу слід постійно прагнути.

Формування міжкультурної компетенції грунтується на принципах:

- пізнання і врахування культурних універсалій;

- культурно-пов'язаного вивчення рідної та іноземної мов;

- етнографічності;

- мовно-поведінкових стратегій;

- усвідомлення та переживання подій;

- управління власними психологічними станами;

- емпатії.

Міжкультурна компетенція являє собою складне утворення, що включає такі компоненти: особливості мислення, стосунки, знання і вміння рідної культури і до культури, що досліджується. Особливості мислення включають: розуміння зв'язку між мовою, мисленням і культурою, здійснення пізнання на межі рідної культури і культури, що досліджується, розуміння рівнозначності і різноманіття культур, критичний погляд на власну культуру і культуру, що досліджується. Відносини включають відкритість, цікавість, готовність відмовитися від упереджень, прийняття культури.

Знання складаються 3 таких компонентів: знання мови, фактів про рідну культуру і культуру, що досліджується, норм соціальної та особистісної взаємодії, лінгвістичних засобів спілкування, культурних цінностей, властивих своїй культурі і культурі, що досліджується.

Уміння передбачають: інтерпретацію культурних фактів, співвідношення подій в рідній і досліджуваній культурах, вилучення та засвоєння нових знань про культуру, застосування знань у практичних ситуаціях спілкування, критичну оцінку своєї та іншої культур. Тільки при гармонійному поєднанні цих компонентів можна говорити про сформованість міжкультурної компетенції особистості. Вивчаючи іноземну мову, студенти долучаються до іншої культури. Викладання мов - це завжди міжкультурне спілкування. Г. Колшанський зазначав, що включення в навчання іноземних мов країнознавчих елементів, культурологічних відомостей, реалій і т.ін., пов'язане не з прагненням надати навчальному процесу цікавість, а з внутрішньою необхідністю самого процесу навчання (Колшанський, 1985). Міжкультурна освіта не передбачає відмову від цінностей рідної культури, навпаки, пізнаючи чужу культуру, студент більш глибоко пізнає і свою власну культуру.

Висновки і перспективи подальших розвідок. 3 огляду на проведене дослідження, доходимо висновку, що одним із завдань сучасної освіти стає створення умов для набуття студентами досвіду міжкультурного спілкування, навчання їх навичкам і вмінням спілкування з представниками інших культур, в процесі якого відбувається формування міжкультурної компетенції на основі принципів взаємної поваги, терпимості до культурних відмінностей і подолання культурних бар'єрів.

Перспективи подальших розвідок вбачаємо у більш глибокому дослідженні різних методів щодо реалізації компетентнісного підходу для вирішення важливих завдань, пов'язаних 3 підготовкою висококваліфікованих кадрів, формуванням у студентів необхідних інструментальних, міжособистісних і системних компетенцій, створенням наукової і навчально-методичної бази для підготовки компетентного фахівця. 


\title{
СПИСОК ВИКОРИСТАНИХ ДЖЕРЕЛ
}

Хомский, Н. (1972). Аспекты теории синтаксиса. Москва: Издательство Московского университета. 259 с.

Savignon, S. (1983). Communicative Competence: Theory and Classroom Practice. Reading, Mass.: Addison-Wesley. Canadian Modern Language Review, 40(3), pp. 464465. URL: https://doi.org/10.3138/cmlr.40.3.464.html [Дата звернення 6 грудня 2019].

Боброва, Т. (2015). Современные подходы в формировании лингвистической, коммуникативной и межъязыковой компетенций в обучении иностранному языку в вузе. URL: http://cprsob.ru/load/21-1-0-91.html [Дата звернення 6 грудня 2019].

Колшанский, Г. (1985). Лингвокоммуникативные аспекты речевого общения. Иностранные языки в школе. 1, С. 13.

\section{REFERENCES:}

Khomskiy, N. (1972). Aspekty teorii sintaksisa [Aspects of Syntax Theory]. Moskva: Izdatelstvo Moskovskogo universiteta (Moscow University Press). 259 s. (in Russian)

Savignon, Sandra J. (1983). Communicative Competence: Theory and Classroom Practice. Reading, Mass.: Addison-Wesley. Canadian Modern Language Review, 40(3), p. 464-465. URL: https://doi.org/10.3138/cmlr.40.3.464.html. (Accessed 06/12/2019)

Bobrova, T. (2015). Sovremennyye podkhody $\mathrm{v}$ formirovanii lingvisticheskoy. kommunikativnoy i mezhyazykovoy kompetentsiy $\mathrm{v}$ obuchenii inostrannomu yazyku $\mathrm{v}$ vuze. [Modern Approaches to the Formation of Linguistic, Communicative and Interlanguage Competencies in Teaching Foreign Language at the University]. URL: http://cprsob.ru/load/21-1-0-91.html (Accessed 06/12/2019) (in Russian)

Kolshanskiy, G. (1985). Lingvokommunikativnyye aspekty rechevogo obshcheniya. [Linguistic and Communicative Aspects of Verbal Communication]. Inostrannyye yazyki v shkole. 1, S. 13. (in Russian)

\section{COMPETENCE APPROACH IN FOREIGN LANGUAGE LEARNING}

\author{
Liudmyla Yasnohurska \\ Ph.D. in Philology, Assistant Professor, \\ Assistant Professor at Foreign Languages Department. \\ Rivne State University for the Humanities, \\ Rivne, Ukraine \\ ORCID: 0000-0003-3039-447X \\ e-mail: ludmila12011@ukr.net
}

\begin{abstract}
This article is dedicated to the implementation of a competent approach in teaching a foreign language at a higher educational establishment. The list of cultural and professional competences that a university student should possess is considered. The importance of the formation of students concerning their intercultural competence in foreign language learning is dictated by the radical changes that are taking place in Ukrainian society as a result of integration of our country into the world educational, information, economic space which in turn forces a person to be able to coexist in this space, i.e. to be engaged in constructive dialogue with all individuals within this space. The orientation of the educational process in the language educational system should be based on the consistent formation of intercultural competence to address specific overarching tasks in the English language learning process. The author states that intercultural competence is not identical to the communicative competence of the native speaker but is an ability that allows the individual to go beyond his or her own culture
\end{abstract}


and to acquire the qualities of a mediator of different cultures while losing his or her own personal cultural identity at the same time. It is emphasized that the communicative competence of a student studying a foreign language communication is the ability to have full language communication in all spheres of human activities in compliance with the social norms of linguistic behavior.

It is also stated that the study of problems of intercultural communication involves acquaintance with the principles of communication, the basic functions of culture, the influence of culture on perception and communication in its various spheres and types, parameters for describing the impact of culture on human activity and development of a certain society.

The author considers the intercultural competence as a complex entity that includes the following components: thinking, attitudes, knowledge, and skills related to both the native culture and the culture under study. Features of thinking include: understanding the connection between language, thinking and culture; realization of knowledge on the border of native culture and culture under study; understanding of equivalence and diversity of cultures.

Keywords: competence, communication, intercultural competences, communication, foreign language. 